\title{
Effects of Operating Pressure, Nozzle Diameter and Wind Speed on the Performance of Sprinkler in Irrigation System during Water Application
}

\author{
Dereje Bishaw Nigatie ${ }^{1 *}$, Megersa O. Dinka ${ }^{2}$, Tilahun Hordofa ${ }^{3}$
}

${ }^{1}$ Researcher in Irrigation Engineering; Research \& Training, Sugar Corporation, ETHIOPIA

${ }^{2}$ Department of Civil Engineering Sciences, Faculty of Engineering and Built Environment, University of Johannesburg, SOUTH AFRICA

${ }^{3}$ Ethiopian Institute of Agricultural Research, ETHIOPIA

*Corresponding Contact:

Email: derejebishaw@yahoo.com

\begin{abstract}
Owing to an increasing demand for irrigation water associated with the massive expansion of irrigated sugarcane farms in Ethiopia, there is a need to use the available water efficiently and effectively. Accordingly, a study was conducted to evaluate the effect of operating pressure and nozzle size on the field performance of dragline sprinkler system at Wonji/Shoa Sugar Estate. The study was conducted under three wind phases (morning, mid-day and late afternoon) using three operating pressures $(250 \mathrm{kPa}, 300 \mathrm{kPa}$ and $350 \mathrm{kPa})$ and two nozzle sizes (4.4 and $4.8 \mathrm{~mm}$ ). Uniformity measurements were performed using single sprinkler and four sprinklers configurations. An application efficiency of low-quarter of $41 \%$ to $80.3 \%$ and actual application efficiency of low-quarter of $30.1 \%$ to $37.5 \%$ were achieved under the respective test combinations. Christiansen's coefficient of uniformity of $71.7 \%$ to $86.3 \%$, and distribution uniformity of $61 \%$ to $80.3 \%$ were achieved under different test combinations for four sprinklers test. The achievable delivery performance ratio was in the range of 0.81 to 1.18 . The experimental results illustrated that, lower operating pressure and higher wind velocity were the major factors responsible for the low water distribution uniformity and efficiency.
\end{abstract}

Keywords: adequacy, efficiency, nozzle diameter, operating pressure, uniformity, wind speed

\section{INTRODUCTION}

Inappropriate design, installation or management of irrigation system could be the reason for the poor performances of sprinkler irrigation (Magwenzi, 2000; Smajstrla et al., 2002). The most important aspects in the sprinkler systems performance is the uniformity of 
water application (Solomon, 1979; Maroufpoor et al., 2010). Uniform water distribution is necessary for maximizing crop yield and quality as well as for more efficient use of the available irrigation water (Ascough and Kiker, 2002).

Many factors affect the uniformity of water application under sprinkler systems, including sprinkler type (model), nozzle type (number and size), operating pressure, riser height, environmental conditions (Keller and Bliesner, 1990; Turjuelo et al., 1999) and the crop to be irrigated (Sanchez et al., 2010). Sprinkler heads are the most important component in the sprinkler system due to the fact that their performance determines the effectiveness and efficiency of the whole system. Wind, temperature and humidity are environmental factors affecting water distribution pattern of sprinkler irrigation (Solomon, 1979; Turjuelo et al., 1999). The uniformity of application is strongly affected by wind speed and direction. According to a report by Playan et al. (2005), wind velocity is the meteorological variable most directly related to sprinkler irrigation performance due to its effects on Christiansen's uniformity coefficient (CU) and on wind drift and evaporation losses (Sanchez et al., 2011). For this reason, irrigation applications should be made when the wind speed is low (Dechmi, 2002) and laterals should be fixed parallel to the dominant wind direction (Kara et al., 2008).

Performance evaluation has a number of advantages in sprinkler irrigation systems. The performance of sprinkler irrigation systems in many areas of the world could be improved in order to save water and energy (Trajuelo et al., 1992). In-field performance evaluation of sprinkler irrigation system is extremely important in realizing the basic aim of efficient and effective application of water. Moreover, it is essential to evaluate the performance of new systems because they should be operating at the designed specification. Data obtained from field evaluation are useful in indicating any defects regarding system operation, water distribution and water losses. Field evaluation also indicates both the location and magnitude of water losses that are occurring, and then determining how to improve the irrigation system and/or its operation. A sprinkler irrigation system is normally evaluated based on uniformity coefficients determined from field measurements using an array of water collecting devices (Topak et al., 2005).

Furrow irrigation system has been in use at Wonji/Shoa sugar estate (WSSE) for irrigating sugarcane crop for more than 50 years. In recent time (2009), sprinkler irrigation systems (dragline-an overhead sprinkler system consists of a mainline with fixed laterals and a flexible hose connects a tripod stand mounted with a sprinkler and center pivot) has been introduced to irrigate additional 2,800 ha of land at Wake-Tio and Dodota sites due to the increasing demand for sugar in Ethiopia and the need to use the available water more efficiently. Even though sprinkler irrigation has started operation in recent years, no critical scientific investigation has been made regarding the actual field performance of the sprinkler systems. The estate does not know whether they are achieving the created performance during design. Evaluating the performance of the system is extremely important in order to understand the status of the design and management performance of the system. The aim of the present study is to assess the effects of operating pressure, nozzle diameter, and wind velocity on the field performance of sprinkler irrigation at Wake-Tio expansion site. The objective is to evaluate the performance of sprinkler irrigation under different technical (nozzle size and operating pressure) and meteorological (wind speed and direction) conditions at the field level. The paper discusses the three most important water application performance parameters of sprinkler irrigation system: uniformity, efficiency and adequacy on different scenarios and give recommendations for improved measures for sprinkler irrigation performance. 


\section{Materials ANd Methods}

\section{Description of the Study Area}

The experiment was carried out at Wake-Tio expansion site of WSSE, which is located at an elevation of $1550 \mathrm{~m}$ above sea level (latitude of $8^{\circ} 24^{\prime} \mathrm{N}$ and longitude of $39^{\circ} 21^{\prime} \mathrm{E}$ ) (Figure 1). Dragline sprinkler irrigation system is used to irrigate the sugarcane fields. Spacing between laterals is $54 \mathrm{~m}$ and the riser valves are placed at an interval of $18 \mathrm{~m}$ on the lateral. The length of the hose is $20 \mathrm{~m}$ which is attached to risers of 4 meter height above the ground. Each sprinkler serves 12 positions on $18 \mathrm{~m} \times 18 \mathrm{~m}$ grid. One sprinkler serves for an area of $(54 \times 72) \mathrm{m}^{2}$ or 0.3888 ha for irrigation. The sprinkler system uses single nozzle of diameter $4.4 \mathrm{~mm}$ with an application rate of $4.7 \mathrm{~mm} / \mathrm{hr}$ at $300 \mathrm{kPa}$ head. The design application efficiency is $75 \%$. The mean annual maximum and minimum daily air temperature is $28.5^{\circ} \mathrm{C}$ and $12.6{ }^{\circ} \mathrm{C}$, respectively. The yearly average precipitation and wind speed is $768 \mathrm{~mm}$ and $2.81 \mathrm{~m} / \mathrm{s}$, respectively. The soils in the study area are described as loams, silty loams and clay loams formed from volcanic derived colluviums and alluvium on plains and terraces.

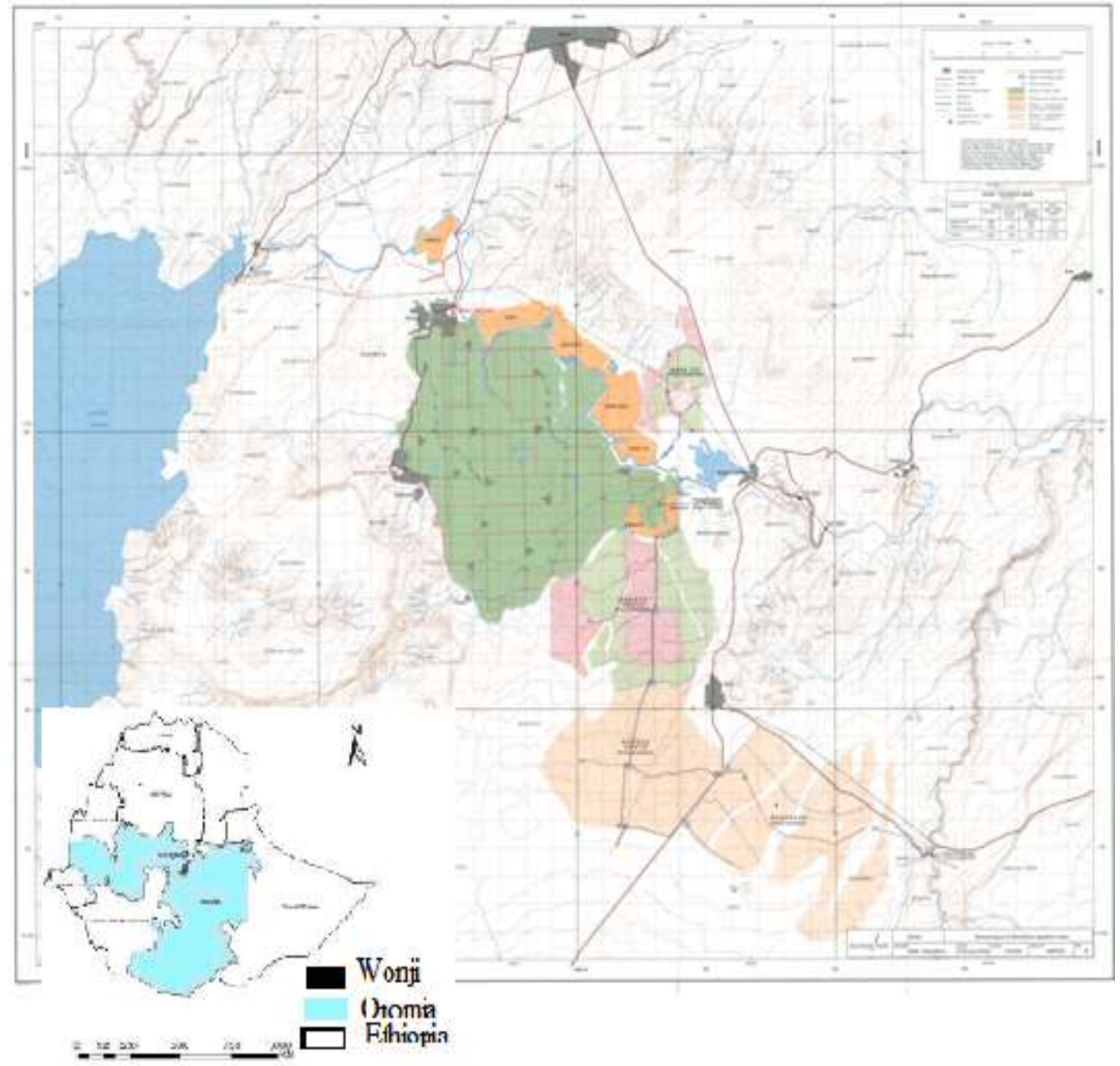

Fig.1. Location map of the study area 


\section{Methods of Data Collection and Analysis}

Three operating pressure levels at the hydrant $(250 \mathrm{kPa}, 300 \mathrm{kPa}$ and $350 \mathrm{kPa})$ and two sprinkler nozzle diameters $(4.4 \mathrm{~mm}$ and $4.8 \mathrm{~mm})$ were used to evaluate the different performance parameters (uniformity, efficiency and adequacy) of the dragline sprinkler irrigation system. Since the evaluation should conduct on blocks where vegetation could not influence water distribution in the catch cans, the study was conducted at first ratoon sugarcane fields immediately after harvesting. To see the effect of wind, the tests were carried out under different wind conditions during early morning (from 6 a.m. to 8 a.m.), mid-day (from 12 a.m. to 2 p.m.) and late afternoon (from 6 p.m. to 8 p.m.).

Field evaluation procedures of Merriam and Keller (1978) and Merriam et al. (1983) were used. The pattern of distribution was evaluated by measuring the precipitation in catch cans at different points in the sprinkled area. In order to calculate the performance indicators (uniformity coefficient, distribution uniformity and application efficiency), measurements were taken on two fields both using four sprinklers and single sprinkler methods. Uniformity measurement with four sprinklers was determined by placing 36 identical and graduated catch cans on a grid between two adjacent lines (laterals) and four sprinklers (Figure 2). The catch can opening diameter was $7.7 \mathrm{~cm}$ and $20 \mathrm{~cm}$ height placed on a level ground surface. Each catch can was placed on plastic pegs of height $22.4 \mathrm{~cm}$. The amount of water collected in the catch cans was recorded directly in $\mathrm{cm}$. Single sprinkler uniformity measurement was under taken by placing a total of 104 catch cans on a $3 \mathrm{~m} \mathrm{x} 3 \mathrm{~m}$ grid system on both sides of the lateral around the sprinkler (Figure 3). On single sprinkler test, total catch can between adjacent lateral positions was simulated by overlapping the right and left side catch can data. In the meantime, during uniformity measurement, climatic data corresponding to each test period were taken from a nearby metrological station.

After completion, the amount of water collected in the catch cans was measured. Furthermore, four catch cans, with $1 \mathrm{~cm}$ depth of water, on each test fields was placed outside the testing area in order to estimate the volume of water lost by evaporation in catch cans, both during the field test and during the reading process. The evaporation in the catch cans was taken into account to determine the potential application efficiency of the low quarter.

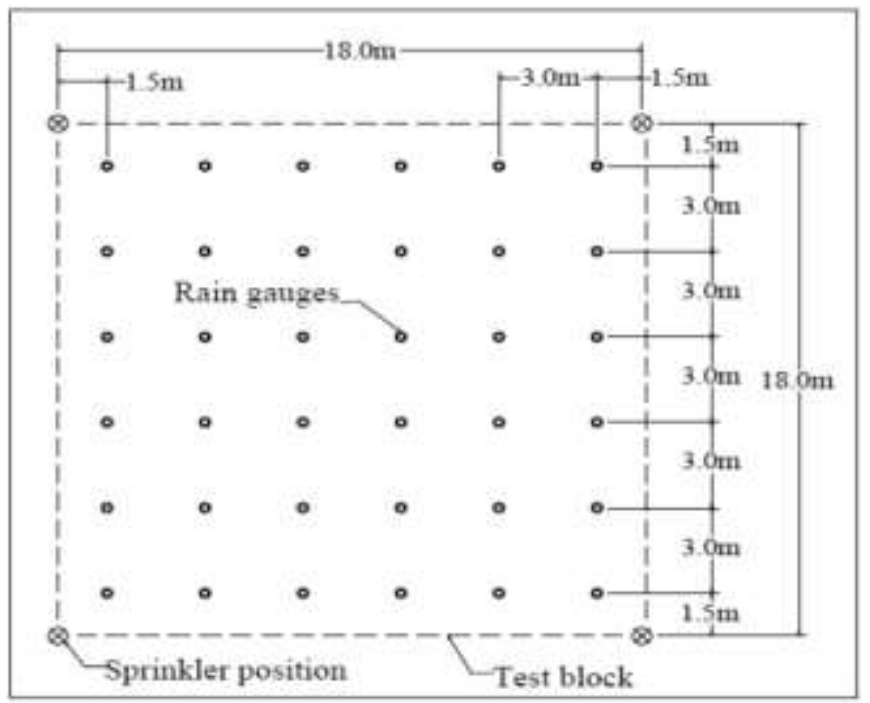

Fig. 2. Rain gauge set-up at a sprinkler system to measure the distribution (four sprinklers) 


\begin{tabular}{|l|l|l|l|l|l|l|l|l|l|l|l|}
\hline & & & & 0 & 0 & 0 & 0 & & & & \\
\hline & & & 0 & 0 & 0 & 0 & 0 & 0 & & & \\
\hline & & 0 & 0 & 0 & 0 & 0 & 0 & 0 & 0 & & \\
\hline & 0 & 0 & 0 & 0 & 0 & 0 & 0 & 0 & 0 & 0 & \\
\hline 0 & 0 & 0 & 0 & 0 & 0 & 0 & 0 & 0 & 0 & 0 & 0 \\
\hline 0 & 0 & 0 & 0 & 0 & 0 & 0 & 0 & 0 & 0 & 0 & 0 \\
\hline 0 & 0 & 0 & 0 & 0 & 0 & 0 & 0 & 0 & 0 & 0 & 0 \\
\hline 0 & 0 & 0 & 0 & 0 & 0 & 0 & 0 & 0 & 0 & 0 & 0 \\
\hline & 0 & 0 & 0 & 0 & 0 & 0 & 0 & 0 & 0 & 0 & \\
\hline & & 0 & 0 & 0 & 0 & 0 & 0 & 0 & 0 & & \\
\hline & & & 0 & 0 & 0 & 0 & 0 & 0 & & & \\
\hline & & & & 0 & 0 & 0 & 0 & & & & \\
\hline
\end{tabular}

\section{$\Varangle$ Sprinkler position \\ o Catch can positions}

Fig. 3. Rain gauge set-up at a sprinkler system to measure the distribution (single sprinkler)

\section{Data Analysis}

Data recorded from both single and four sprinklers tests were used to determine the basic sprinkler performance parameters. The basic performance indicators used in this study were the Christiansen's Coefficient of Uniformity (CU), Distribution Uniformity (DU), Potential Application Efficiency of Low-Quarter (PELQ), Actual Application Efficiency of Low-Quarter (AELQ) and low-quarter Adequacy (which is expressed as Delivery Performance Ratio-DPR). The considered basic performance indicators were calculated as suggested by Merriam and Keller (1978) and Merriam et al. (1983). A correlation model was adapted to analyze the relation of the performance indicator parameters to that of the design and climatic parameters. The wind distortion pattern on the sprinkler spray was identified by developing and digitizing the precipitation profile using the computer program called SURFER (ver.8). Grid-based maps of contour and wireframes maps were produced from the grid files.

\section{RESULTS AND DISCUSSION}

\section{Application Efficiency}

Table 1 presents PELQ, CU and DU values for different sprinkler combinations for four sprinklers tests. The minimum value of PELQ was $41 \%$ at $300 \mathrm{kPa}$ operating pressure and $4.4 \mathrm{~mm}$ nozzle diameter during mid-day test; whereas the maximum PELQ was $80.3 \%$ at $350 \mathrm{kPa}$ operating pressure and $4.8 \mathrm{~mm}$ nozzle diameter during morning time test. The average wind speed was $4.42 \mathrm{~m} / \mathrm{s}$ and $1.96 \mathrm{~m} / \mathrm{s}$ for the respective minimum and maximum values of PELQ. All the values recorded during mid-day time were below $60 \%$ because of high wind speed occurred during the test. Low value of PELQ indicates poor system design and causes excessive quantities of water losses. Wind distortions, low operating pressure and leakage all contribute to the poor performance of the system. Megersa (2004) reported PELQ values of $63 \%$ to $76 \%$ for drag line sprinkler at Finchaa sugar estate (FSE). The difference in PELQ values at WSSE and FSE is obviously due to the variations in wind speed and direction in the two areas. 
Nigatie et al: Effects of Operating Pressure, Nozzle Diameter and Wind Speed on the Performance of Sprinkler in Irrigation System during ...... (45-56)

Table 1- Average PELQ, CU and DU values for different sprinkler combinations for four sprinklers test $(\%)$

\begin{tabular}{|c|c|c|c|c|c|c|c|c|c|}
\hline \multirow[b]{2}{*}{$\begin{array}{l}\text { Operating } \\
\text { pressure }\end{array}$} & \multirow[b]{2}{*}{$\begin{array}{c}\text { Wind } \\
\text { condition }\end{array}$} & \multicolumn{4}{|c|}{$4.4 \mathrm{~mm}$ nozzle diameter } & \multicolumn{4}{|c|}{$4.8 \mathrm{~mm}$ nozzle diameter } \\
\hline & & $\begin{array}{l}\text { Wind } \\
\text { speed } \\
(\mathrm{m} / \mathrm{s})\end{array}$ & PELQ & CU & DU & $\begin{array}{l}\text { Wind } \\
\text { speed } \\
(\mathrm{m} / \mathrm{s})\end{array}$ & PELQ & $\mathrm{CU}$ & DU \\
\hline \multirow{6}{*}{2.5 bar } & Morning & 2.28 & 57.70 & 74.30 & 65.30 & 2.84 & 68.30 & 82.30 & 76.30 \\
\hline & Mid-day & 2.96 & 50.30 & 71.70 & 61.00 & 2.79 & 56.00 & 80.70 & 66.00 \\
\hline & Late afternoon & 1.73 & 61.00 & 79.00 & 71.30 & 2.34 & 58.70 & 85.30 & 76.00 \\
\hline & \multirow{3}{*}{$\begin{array}{l}\text { Mean } \\
\text { St. dev } \\
\text { CV }(\%)\end{array}$} & 2.32 & 56.33 & 75.00 & 65.87 & 2.66 & 61.00 & 82.77 & 72.77 \\
\hline & & 0.62 & 5.48 & 3.70 & 5.17 & 0.28 & 6.46 & 2.34 & 5.86 \\
\hline & & 26.52 & 9.73 & 4.93 & 7.85 & 10.37 & 10.60 & 2.82 & 8.06 \\
\hline \multirow{6}{*}{$3.0 \mathrm{bar}$} & Morning & 2.26 & 75.70 & 81.70 & 75.70 & 1.98 & 61.00 & 86.00 & 76.30 \\
\hline & Mid-day & 4.42 & 41.00 & 73.30 & 63.70 & 3.94 & 44.70 & 77.70 & 65.30 \\
\hline & Late afternoon & 2.02 & 49.30 & 80.70 & 73.00 & 1.57 & 61.00 & 85.30 & 77.30 \\
\hline & \multirow{3}{*}{$\begin{array}{l}\text { Mean } \\
\text { St. dev } \\
\text { CV (\%) }\end{array}$} & 2.90 & 55.33 & 78.57 & 70.80 & 2.50 & 55.57 & 83.00 & 72.97 \\
\hline & & 1.32 & 18.12 & 4.59 & 6.30 & 1.27 & 9.41 & 4.60 & 6.66 \\
\hline & & 45.58 & 32.75 & 5.84 & 8.89 & 50.73 & 16.94 & 5.55 & 9.13 \\
\hline \multirow{6}{*}{3.5 bar } & Morning & 1.66 & 72.30 & 79.30 & 71.30 & 1.96 & 80.30 & 86.30 & 80.30 \\
\hline & Mid-day & 4.13 & 45.30 & 73.00 & 66.70 & 4.04 & 56.30 & 83.30 & 77.00 \\
\hline & Late afternoon & 2.30 & 50.30 & 79.30 & 70.00 & 1.80 & 69.00 & 84.70 & 75.00 \\
\hline & \multirow{3}{*}{$\begin{array}{l}\text { Mean } \\
\text { St. dev } \\
\text { CV (\%) }\end{array}$} & 2.70 & 55.97 & 77.20 & 69.33 & 2.60 & 68.53 & 84.77 & 77.43 \\
\hline & & 1.28 & 14.36 & 3.64 & 2.37 & 1.25 & 12.01 & 1.50 & 2.68 \\
\hline & & 47.54 & 25.67 & 4.71 & 3.42 & 48.06 & 17.52 & 1.77 & 3.46 \\
\hline
\end{tabular}

The variation in PELQ is strongly correlated (negative) with wind speed in both nozzle diameters (4.4 and $4.8 \mathrm{~mm}$ ) and operating pressures $(250 \mathrm{kPa}, 300 \mathrm{kPa}$ and $350 \mathrm{kPa})$ except nozzle diameter $4.8 \mathrm{~mm}$ at $250 \mathrm{kPa}$ operating pressure which shows weak positive correlation. Also variation in PELQ is strongly correlated (positive) with CU and DU in both nozzle diameters (4.4 and $4.8 \mathrm{~mm})$ and operating pressures $(250 \mathrm{kPa}, 300 \mathrm{kPa}$ and 350 $\mathrm{kPa}$ ) except nozzle diameter $4.8 \mathrm{~mm}$ at 2.5 bar operating pressure which shows no correlation with CU.

Since the potential efficiency does not indicate the level of adequacy and uniformity, the actual application efficiency of the low quarter (AELQ) was determined based on the low quarter depth of water infiltrated and stored in the effective root zone (Table 2). The values of AELQ obtained from different combination tests were below $40 \%$. The lowest AELQ was $30.1 \%$ at $350 \mathrm{kPa}$ and $4.8 \mathrm{~mm}$ nozzle diameter and the highest AELQ was $37.5 \%$ at $300 \mathrm{kPa}$ and $4.4 \mathrm{~mm}$ nozzle diameter (Table 2). This implied that $62.5 \%$ to $69.9 \%$ of the applied water was lost as deep percolation below the effective root zone and as surface evaporation from the cane fields. Megersa (2004) obtained AELQ value ranging from 29\% to $32 \%$ for luvisol and $46 \%$ to $52 \%$ for vertisol in his evaluation at Finchaa sugar estate.

The difference between PELQ and AELQ implies poor operation management of the system. Low value of AELQ is an indication of management problem. So by alleviating management problems it is possible to increase the AELQ to PELQ. The best option to reduce this gap is adjusting the sprinkler set time based on the sprinkler discharge rate and the water requirement of sugarcane. Ismail et al. (1996) and Lecina et al., (2005) stated that properly designed and managed sprinkler system can possibly improve efficiency of the system. As suggested by Nasab et al. (2007) selecting adequate time step and sufficient irrigation can enhance the actual efficiency of the system to meet the potential efficiency. 
Table 2- AELQ determined from four sprinklers test (\%)

\begin{tabular}{|c|c|c|c|}
\hline & $\begin{array}{c}2.5 \text { bar } \\
\text { operating pressure }\end{array}$ & $\begin{array}{c}3.0 \text { bar } \\
\text { operating pressure }\end{array}$ & $\begin{array}{c}3.5 \text { bar } \\
\text { operating pressure }\end{array}$ \\
\hline $4.4 \mathrm{~mm}$ nozzle diameter & 35.1 & 37.5 & 34.3 \\
\hline $4.8 \mathrm{~mm}$ nozzle diameter & 35.5 & 34.6 & 30.1 \\
\hline
\end{tabular}

\section{Water distribution uniformity}

The evaluation of operating pressure, nozzle size and wind speed on the water distribution pattern of sprinkler system was obtained by catching water from single sprinkler and four sprinklers.

\section{Single Sprinkler Test}

Table 3 shows the average CU and DU values of a single sprinkler test at different operating pressure, nozzle size and wind conditions. Over all testing conditions, CU value ranged from $67.7 \%$ at mid-day test to $85.7 \%$ at late afternoon test and DU value ranged from $53.9 \%$ to $77.9 \%$ were obtained. DU of $53.9 \%$ showed that the low quarter of the area received only $53.9 \%$ of the average. This means that under irrigation could occur in the test area.

Variation in wind speed across the irrigation events is strongly (negative) correlated with CU and DU except in $300 \mathrm{kPa}$ operating pressure at $4.4 \mathrm{~mm}$ nozzle diameter and $350 \mathrm{kPa}$ operating pressure at $4.8 \mathrm{~mm}$ nozzle diameter which show weak (negative) correlation and strongly (positive) correlation with CU and DU, respectively. This indicating that wind speed is more important than operating pressure and nozzle diameter. Variation in CU is significantly correlated with DU in all test combinations.

Table 3- CU and DU values for different sprinkler combinations for single sprinkler test

\begin{tabular}{|c|c|c|c|c|c|c|c|}
\hline & & \multicolumn{3}{|c|}{$4.4 \mathrm{~mm}$ nozzle diameter } & \multicolumn{3}{|c|}{$4.8 \mathrm{~mm}$ nozzle diameter } \\
\hline $\begin{array}{c}\text { Operating } \\
\text { pressure }\end{array}$ & $\begin{array}{c}\text { Wind } \\
\text { condition }\end{array}$ & $\begin{array}{l}\text { Wind } \\
\text { speed } \\
(\mathrm{m} / \mathrm{s})\end{array}$ & CU (\%) & DU (\%) & $\begin{array}{l}\text { Wind } \\
\text { speed } \\
(\mathrm{m} / \mathrm{s})\end{array}$ & $\mathrm{CU}(\%)$ & DU $(\%)$ \\
\hline \multirow{6}{*}{2.5 bar } & Morning & 2.82 & 70.00 & 59.10 & 3.22 & 76.20 & 63.70 \\
\hline & Mid-day & 3.18 & 67.70 & 54.00 & 3.39 & 70.10 & 53.90 \\
\hline & Late afternoon & 2.47 & 74.20 & 70.10 & 1.60 & 85.70 & 77.90 \\
\hline & Mean & 2.82 & 70.63 & 61.07 & 2.74 & 77.33 & 65.17 \\
\hline & St. dev & 0.36 & 3.30 & 8.23 & 0.99 & 7.86 & 12.07 \\
\hline & $\mathrm{CV}(\%)$ & 12.57 & 4.67 & 13.47 & 36.10 & 10.17 & 18.52 \\
\hline \multirow{6}{*}{3.0 bar } & Morning & 3.23 & 71.80 & 65.10 & 3.47 & 81.50 & 71.20 \\
\hline & Mid-day & 3.10 & 75.90 & 65.50 & 2.62 & 83.50 & 70.70 \\
\hline & Late afternoon & 1.94 & 75.30 & 65.40 & 3.05 & 78.10 & 60.50 \\
\hline & Mean & 2.76 & 74.33 & 65.33 & 3.05 & 81.03 & 67.47 \\
\hline & St. dev & 0.71 & 2.21 & 0.21 & 0.43 & 2.73 & 6.04 \\
\hline & $\mathrm{CV}(\%)$ & 25.76 & 2.98 & 0.32 & 14.1 & 3.37 & 8.95 \\
\hline \multirow{6}{*}{3.5 bar } & Morning & 3.65 & 72.20 & 63.10 & 3.35 & 80.70 & 70.30 \\
\hline & Mid-day & 2.59 & 76.30 & 65.50 & 2.85 & 71.50 & 56.70 \\
\hline & Late afternoon & 2.20 & 77.70 & 66.90 & 3.24 & 83.90 & 75.80 \\
\hline & Mean & 2.81 & 75.40 & 65.17 & 3.15 & 78.70 & 67.60 \\
\hline & St. dev & 0.75 & 2.86 & 1.92 & 0.26 & 6.44 & 9.83 \\
\hline & $\mathrm{CV}(\%)$ & 26.67 & 3.79 & 2.95 & 8.35 & 8.18 & 14.54 \\
\hline
\end{tabular}




\section{Four Sprinklers Test}

By considering the overlap of four sprinklers, the average CU value ranges from 193 $71.7 \%$ to $86.3 \%$. Highest value of CU was obtained at low wind speed. DU value ranges from $61 \%$ to $80.3 \%$ (Table 1 ). $72 \%$ of CU and $55.5 \%$ of DU values obtained were below the recommended $84 \%$ and $75 \%$ by Keller and Bliesner (1990), respectively. The uniformity improved as nozzle size increased. Similar result was reported by AboGhobar and Al-Amoud (1992).

High uniformity was obtained in low wind speed conditions and generally mid-day test results were lower than morning and late afternoon tests because of high wind speed occurred at this time. Osei (2009) obtained an average CU and DU values of $87 \%$ and $82.8 \%$, respectively in four sprinkler tests. In his study a higher CU was obtained during higher wind speed. As asserted by Merkley and Allen (2004), occasionally wind can help improve uniformity as the randomness of wind turbulence and gusts contribute to smoothening out the distribution pattern. This was also observed in some combinations of our study, in which uniformity increased with some increase of wind speed.

Variation in wind speed across the irrigation events is strongly (negative) correlated with $\mathrm{CU}$ and DU in all test combinations except in $350 \mathrm{kPa}$ operating pressure at $4.8 \mathrm{~mm}$ nozzle diameter in which variation in wind speed is not correlated with DU. And also variation in CU across the irrigation events is strongly correlated to DU in all test combinations.

As compared to the single sprinkler test generally the $\mathrm{CU}$ and DU values are higher in four sprinklers test. Water depth applied to fields was increased due to overlapping and low spots caused by wind distortion were reduced. Montero et al. (2000) stated that higher uniformity is attained in four sprinkler tests than in single sprinkler tests. This effect may be reasonable, since when some sprinklers are simultaneously irrigating, both wind speed and direction may compensate water distribution in different areas.

\section{Water Delivery Performance}

Delivery performance ratio (DPR) is the simplest indicator that could be used by irrigation managers to assess performance of operation. It could be used to assess adequacy as it gives information on the amount of water delivered in comparison with the amount of water intended to be delivered at a given location in the field. The ratio of the data generated from the discharge tests to that of the expected sprinkler discharge was used to compute DPR of the sprinkler system which is a measure of the system performance. The expected sprinkler discharge is $1.3 \mathrm{~m} 3 / \mathrm{h}$ with an application efficiency of $75 \%$. The average delivery performance ratio ranged from 0.81 to 1.18 (Table 4). The adequacy level of 1.18 indicated the delivery is adequate and at least $18 \%$ of excess water was discharged. From

Table 4 it can be observed that DPR increased as operating pressure as well as nozzle size increased. The result of DPR obtained in this study is in agreement with other similar studies (Megersa, 2004; Ahaneku, 2010).

Table 4: Adequacy of water delivery performance ratio for different sprinkler combinations

\begin{tabular}{|c|c|c|c|}
\hline & $\begin{array}{c}2.5 \text { bar } \\
\text { operating pressure }\end{array}$ & $\begin{array}{c}3.0 \text { bar } \\
\text { operating pressure }\end{array}$ & $\begin{array}{c}3.5 \text { bar } \\
\text { operating pressure }\end{array}$ \\
\hline $4.4 \mathrm{~mm}$ nozzle diameter & 0.81 & 0.83 & 0.87 \\
\hline $4.8 \mathrm{~mm}$ nozzle diameter & 1.08 & 1.18 & 1.11 \\
\hline
\end{tabular}




\section{Impact of Wind Speed on Water Application Uniformity}

Effect of wind speed on water application uniformity was clearly shown that uniformity coefficient was decreased as wind speed increased. Uniformity coefficients were high in late afternoon test because of low wind speed at this time. Dechmi et al. (2003a) reported that a significant portion of CU variability was explained by wind speed alone. Several studies have shown that wind velocity is the main constraint for sprinkler irrigation which severely reduces irrigation uniformity and increases evaporation and drift water losses. On the other hand low wind speed conditions guaranteed for high irrigation uniformity (Dechmi et al., 2003b; Kara et al., 2008; Playan et al., 2009; Moazed et al., 2010; Yacoubi et al., 2010) which was also observed in this study. The CU values decreased as the wind speed increased. Trajuelo et al. (1992) suggested that, in order to obtain a CU value superior to $80 \%$ try not to irrigate with wind speeds higher than $3 \mathrm{~m} / \mathrm{s}$ on the $18 \mathrm{~m} \times 18 \mathrm{~m}$ rectangular spacing.

Effect of wind on water distribution precipitation profile was determined using SURFER computer program for single sprinkler irrigation. The contour and $3 \mathrm{D}$ water distribution precipitation profile for different combinations is given in Fig. 2. Fields irrigated under high wind speed have shown that the water distribution was affected by wind and the distortion followed the direction of wind. Part of the field against the wind direction got less water. Because of this water distribution was affected and resulted in non-uniform water application. Random variation of wind speed and direction and the effect of nozzle size and operating pressure may be the reason for the variation of CU and DU under different wind speeds.
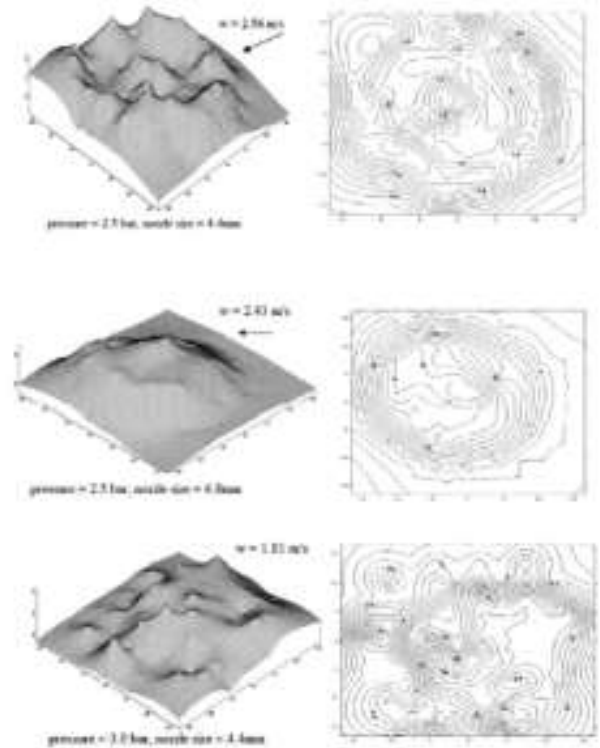
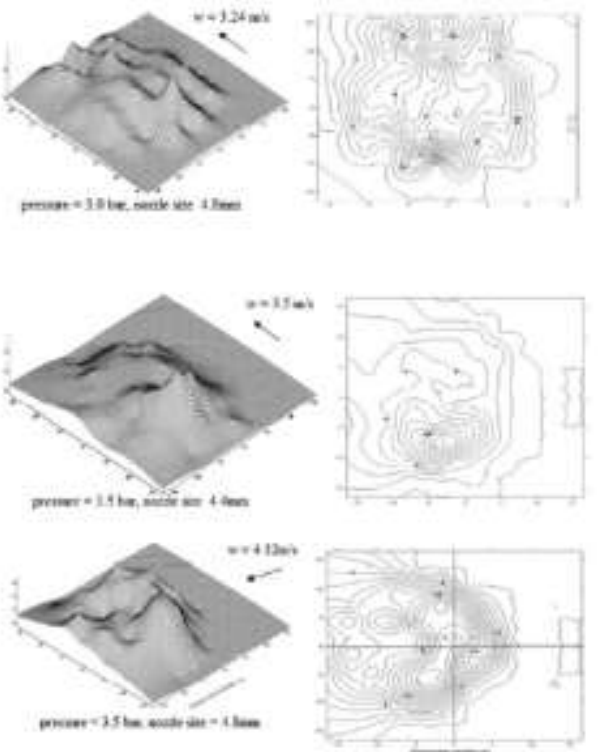

Fig. 2. Water distribution profiles for different combinations under different wind speed and direction 532x327mm $(96 \times 96 \mathrm{DPI})$

\section{Conclusions}

The average PELQ varied between $41 \%$ to $83.3 \%$. As a result of increased wind speed PELQ decreased almost in all test combinations. Better results were obtained in morning and late afternoon time tests relatively when the wind speed was low. The wind speed significantly correlated with PELQ in all test combinations. Consequently, large amount of 
applied water were lost as deep percolation and surface evaporation due to high climatic condition. As a result, the AELQ obtained was generally low as compared to the expected efficiency of sprinkler system.

The highest uniformity coefficient was obtained at $300 \mathrm{kPa}$ operating pressure while the lowest was obtained at $250 \mathrm{kPa}$ operating pressure. The $4.8 \mathrm{~mm}$ nozzle size resulted in higher water distribution uniformity and it can be concluded that uniformity increased as the nozzle size increased. In addition, the wind speed is significantly correlated with coefficient of uniformity and distribution uniformity. Generally the results of CU and DU obtained were almost lower than the required values. The results of adequacy also indicated that over irrigation was observed in about $50 \%$ of the respective test combinations and the rest $50 \%$ of the test combinations showed under irrigation. Except for some test combinations, adequacy level is generally satisfactory in order to meet crop water needs.

The result indicated that more attention needs to be paid to the uniformity of the irrigation system. Even if the effects of wind speed, operating pressure and nozzle diameter is significant; altering those variables does not lead to the necessary and significant gains in performance that are required. Therefore, it is important in reducing run time to maximize $\mathrm{AE}$ and reduce the sprinkler spacing to maximize $\mathrm{CU}$.

\section{ACKNOWLEDGEMENTS}

The first author is thankful to the Ethiopian Sugar Corporation, especially the Research and Training staff members for their support during data collection.

\section{REFERENCES}

Abo-Ghobar M, Al-Amoud AI (1992). Performance characteristics of various impact sprinkler types locally used. J. King Saud Univ. Agric. Sci. 4 (2): 75-187.

Ahaneku IE (2010). Performance evaluation of portable sprinkler irrigation system in Llorin, Nigeria. Indian J. Sci. Technol.3 (7): 853-857.

Ascough GW, Kiker GA (2002). The effect of irrigation uniformity on irrigation water requirements. Water SA 28 (2): 235-242.

Dechmi F (2002). Water management in sprinkler irrigation systems in the Ebro Valley: Current 289 situation and scenario simulations. A Ph.D. Dissertation Presented to Universitat de lleida, Zaragoza, Spain.

Dechmi F, Playan E, Faci J, Tejero M, Bercero A (2003a). Analysis of an irrigation district in NorthEastern Spain: II: Irrigation evaluation, simulation and scheduling. Agric. Water Manage 61: 93-109.

Dechmi F, Playán J, Cavero J, Faci JM, Martínez-Cob A (2003b). Wind effects on solid set sprinkler irrigation depth and corn yield. Irrigation Science 22: 67-77.

Ismail, Samir M, Metwafly Al, Sabbah MA (1996). Irrigation systems evaluation in desert farming. Desert Development Center (DDC), American University in Cairo (AUC), Egypt.

Kara T, Ekmekci E, Apan M (2008). Determining the uniformity coefficient and water distribution characteristics of some sprinklers. Pak. J. Biol. Sci. 11 (2): 214-219.

Keller J, Bliesner RD (1990). Sprinkler and trickle irrigation. Van Nestrand Reinhold. New York.

Lecina S, Playan E, Isidoro D, Dechmi F, Causape J, Faci JM (2005). Irrigation evaluation and simulation at the Irrigation District V of Bardenas (Spain). Agric. water Manage 73: 223-245.

Magwenzi OE (2000). Evaluation of irrigation efficiency in the Swaziland sugar industry. Swaziland Sugar Association Extension Services. Proc. S Afr Sug Technol Ass 74:151-156. 
Maroufpoor E, Faryabi A, Ghamarnia H, Moshrefi G (2010). Evaluation of uniformity coefficients for Sprinkler irrigation systems under different field conditions in Kurdistan Province (Northwest of Iran). Soil \& Water Res. 5 (4): 139-145.

Megersa O (2004). Evaluation of the field water application performance of sprinkler irrigation system at Finchaa sugar estate. An MSc Thesis submitted to Arbaminch University, Ethiopia.

Merkley GP, Allen RG (2004). Sprinkle and trickle irrigation lecture notes. Utah State University, USA.

Merriam JL, Keller J (1978). Farm irrigation system evaluation: A Guide for Management. Department of Agricultural and Irrigation Engineering, Utah State University, Logan, U.S.A.

Merriam JL, Shearer MN, Burt CM (1983). Evaluating irrigation systems and practices, in: Jensen ME. Design and Operation of Farm Irrigation Systems. Irrigation and drainage Notes. Michigan, U.S.A.

Moazed H, Bavi A, Boroomand-Nasab S, Naseri A, Albaji M (2010). Effects of climatic and hydraulic parameters on water uniformity coefficient in solid set systems. J. Applied Sci. 10 (16): 1792-1796.

Montero J, Tarjuelo JM, Ortega JF (2000). Heterogeneity analysis of the irrigation in fields with medium size sprinklers. CIGR 2: 1682-1130.

Nasab SB, Baradanare-Hezave F, Behzad M (2007). Technical evaluation of sprinkler irrigation 322 systems in Akra, Iran. J. Applied Sci. 7 (21): 3338-3341.

Osei, FKB (2009). Evaluation of sprinkler irrigation system for improved maize seed production for farmers in Ghana. An MSc. thesis submitted to the department of agricultural engineering, Kwame Nkrumah university of science and technology, Ghana.

Playan E, Burguete J, Zapata N, Salvador R, Capetillo CB, Cavero1 JA, Cob M, Faci J, Dechmi F (2009). Mathematical problems and solutions in sprinkler irrigation. Monograf'ias de la Real Academia de Ciencias de Zaragoza 31: 153-174.

Playan E, Salvador R, Faci JM, Zapata N, Martinez-Cob A, Sanchez I (2005). Day and night wind drift and evaporation losses in sprinkler solid-sets and moving laterals. Agric. Water Manage 76: 139-159.

Sanchez I, Facia JM, Zapata, N (2011). The effects of pressure, nozzle diameter and meteorological conditions on the performance of agricultural impact sprinklers. Agric. Water Manage 102: 13-24.

Sanchez I, Zapata N, Faci JM (2010). Combined effect of technical, meteorological and agronomical factors on solid-set sprinkler irrigation: I. Irrigation performance and soil water recharge in alfalfa and maize. Agric. Water Manage 97: 1571-1581.

Smajstrla AG, Boman, BJ, Clark, GA, Haman, DZ, Harrison, DS, Izuno, FT, Pitts, DJ, Zazueta FS (2002). Efficiencies of Florida agricultural irrigation systems. Florida Cooperative Extension Service, Institute of Food and Agricultural Sciences, University of Florida, BUL. 247.

Solomon KH (1979). Variability of sprinkler coefficient of uniformity test results. Transactions of the ASAE 22: 1078-1086.

Tarjuelo, JM, Montero J, Honrubia FT, Ortiz JJ, Ortega JF (1999). Analysis of uniformity of sprinkler irrigation in a semi-arid area. Agric. Water Manage 40: 315-331.

Topak R, Suheri S, Ciftci N, Acar B (2005). Performance evaluation of sprinkler irrigation in a semiarid area. Pak. J. Biol. Sci. 8 (1): 97-103.

Trajuelo JM, Valiente M, Lozoya J (1992). Working conditions of a sprinkler to optimize the application of water. J. Irrig. and Drain. 118: 895-913.

Yacoubi S, Zayani K, Zapata N, Zairi A, Slatni A, Salvador R, Playan E (2010). Day and night time sprinkler irrigated tomato: Irrigation performance and crop yield. Agric. Water Manage 107: 25-35. 
Nigatie et al:: Effects of Dperating Pressure, Nozzle Diameter and Wind Speed on the Performance of Sprinkler in Irrigation System during ...... (45-55) 